\title{
Kajian Tentang Rancang Bangun Benteng Kompeni di Jepara
}

Novida Abbas

Keywords: fort, VOC, colonial, Dutch, architecture, archaeology

\section{How to Cite:}

Abbas, N. Kajian Tentang Rancang Bangun Benteng Kompeni di Jepara. Berkala Arkeologi, 14(1), 16-27. https://doi.org/10.30883/jba.v14i1.626

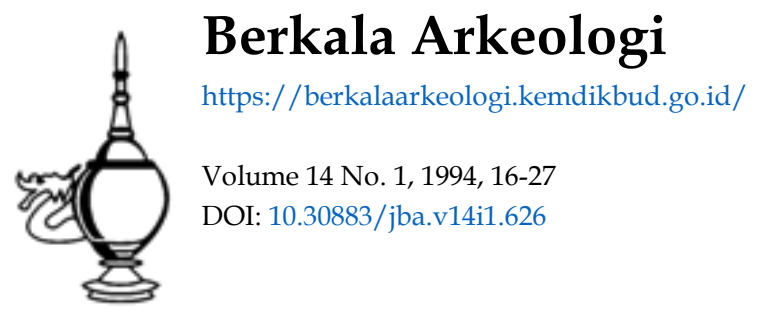

\section{(c) (i) (3)}

This work is licensed under a Creative Commons Attribution-NonCommercial-ShareAlike 4.0 International License. 


\title{
KAJIAN TENTANG RANCANG BANGUN BENTENG KOMPENI DI JEPARA
}

\author{
Novida Abbas \\ (Balai Arkeologi Yogyakarta)
}

\begin{abstract}
Salah satu sarana pertahanan yang berasal dari masa kolonial di Jawa adalah benteng-benteng Belanda, yang beberapa di antaranya ma-sih dapat disaksikan bekas-bekasnya hingga kini. Keberadaan benteng-benteng tersebut menyiratkan adanya konflik antara kelompokkelompok masyarakat di Nusantara melawan kolonial, yang memaksa pihak kolonial untuk mendirikan berbagai sarana pertahanan guna menangkal upaya perjuangan rakyat tersebut. Di antara sejumlah bekas benteng Belanda di Jawa, salah satu yang masih dapat disaksikan adalah sebuah benteng yang terdapat di Jepara. Benteng yang dikenal dengan sebutan Benteng VOC atau Benteng Kompeni ini terletak di wilayah Dusun Ujung Batu, Desa Ujung Batu, Kecamatan Jepara, Kabupaten Jepara, Propinsi Jawa Tengah. Tepatnya benteng tersebut terletak di puncak sebuah bukit yang menghadap ke Laut Jawa. Bukit tersebut dikenal dengan sebutan Bukit Danareja atau Bukit Jepara (de Graaf, 1987:155). Dari pusat kota Jepara, benteng ini berjarak sekitar $0,5 \mathrm{~km}$. Secara astronomis benteng ini terletak pada $6^{\circ} 35^{\prime} 9^{\prime \prime}$ LS dan $3^{\circ} 51^{\prime} 49^{\prime \prime}$ BT meridian Jakarta.
\end{abstract}

Kepastian tentang masa pendirian benteng ini belum diketahui. Be-berapa sumber hanya menyebut tentang masa penggunaan benteng ter-sebut, yaitu sekitar abad XVII M (de Graaf, 1989:7; de Graaf, 1987:155, 166; de Graaf, 1949:211, 220, 243). Pada masa itu terjadi konflik antara Trunajaya melawan Sunan Amangkurat I, dan berlanjut pada masa Su-nan Amangkurat II yang mendapat bantuan pihak Kompeni. Antara lain disebutkan dalam sumber-sumber tersebut bahwa setelah mendirikan loji di Jepara pada tahun 1651, Belanda juga memiliki ben-teng di bukit, ya-itu setelah Bukit Danareja diduduki Speelman pada tahun 1677. Setelah itu Letnan Martinus van Ingen membuat gambar daerah itu dan merenca-nakan akan menempatkan 100 serdadu Belanda di benteng itu di bawah pimpinan seorang 
letnan. ${ }^{1}$ Pada masa itu penguasa Jepara adalah Ngabei Wangsadipa, yang memberi Kompeni 5 pucuk meriam untuk mempertahankan kota Jepara. Dari 5 pucuk meriam itu di antaranya ada yang ditempatkan di Bukit Danareja (Olthoff, 1941:165; de Graaf, 1987:94-95). Disebutkan pula bahwa pasukan-pasukan Trunajaya berkali-kali menyerang benteng ini dengan sia-sia. Benteng ini kemudian ditinggalkan pada awal abad XVIII M, yaitu ketika para serdadu Belanda pindah dari Danareja ke sebuah benteng berdenah segi lima di Semarang (de Graaf, 1949:243).

Benteng Kompeni yang terletak di puncak Bukit Danareja atau Bukit Jepara ini mempunyai arah hadap ke timur. Areal sisi timur benteng memang merupakan daerah yang cukup landai, sedangkan sisi-sisi lainnya terjal. Saat ini lereng barat laut benteng digunakan sebagai tempat pemakaman penduduk sekitar; sisi timur benteng merupakan kompleks pemakaman Belanda, Cina, serta Taman Makam Pahlawan Giri Dharma; di lereng selatan terdapat rumah- rumah penduduk; sedangkan di sebelah barat laut dapat disaksikan Pantai Laut Jawa. Di kaki bukit sisi selatan terdapat Sungai Wiso yang mengalir ke arah barat (Gambar 1).

Benteng tersebut berdenah segi tiga dengan tiga bastion di ketiga sudutnya (Gambar 2). Tembok keliling benteng mempunyai ketebalan $60 \mathrm{~cm}$. Bahan yang digunakan adalah batu karang yang dibentuk menjadi balok-balok batu persegi panjang (Foto 1). Ukuran balok-balok batu karang tersebut berkisar antara: panjang $47-60 \mathrm{~cm}$, lebar $17-20$ $\mathrm{cm}$, dan tebal $22-25 \mathrm{~cm}$. Balok-balok batu tersebut disusun dengan menggunakan perekat berupa campuran pasir, kapur, dan semen merah, serta tidak menggunakan lepa.

Panjang dinding sisi barat $56,5 \mathrm{~m}$, sisi selatan $56 \mathrm{~m}$, dan sisi timur $74 \mathrm{~m}$. Tinggi dinding keliling yang masih tersisa adalah 0,75-1 m (diukur dari permukaan tanah bagian dalam benteng) (Foto 2). Pada dinding keliling sisi timur terdapat bekas pintu masuk benteng selebar

1 Dari catatan Belanda diketahui bahwa pada tahun 1685 d Jepara terdapat 107 pasukan Kompeni, selanjutnya pada tahun 1686 meningkat menjadi 1144 serdadu, d tahun 1693 tercatat 793 serdadu, dan di tahun 1703 terdapat 386 serdadu (de Graaf, 1989:95-96) 
8,3 m. Sebagian dinding keli- ling sisi barat, yaitu tepat pada sambungan antara dinding tersebut dengan bastion timur laut, saat ini telah runtuh.

Ketiga bastion pada sudut-sudut benteng berdenah menyerupai bentuk ujung tombak. Ketiga bastion itu masing-masing terdapat di sudut barat daya, timur laut, dan tenggara. Bagian dalam ketiga bastion tersebut permukaan tanahnya lebih tinggi dari pada permukaan bagian dalam benteng. Pada bagian ujung (sudut) ketiga bastion tersebut terdapat bangunan pengintaian berdenah bulat berbahan bata. Satusatunya bangunan pengintaian yang masih berdiri adalah yang terdapat di bastion barat laut. Garis tengah bagian dalam bangunan tersebut adalah $90 \mathrm{~cm}$, sedangkan tebal dindingnya $15 \mathrm{~cm}$. Kedua bangunan pengintaian lainnya hanya tersisa fondasinya saja. Dari bangunan pengintaian yang masih berdiri, tampak bahwa dulunya bangunan tersebut menggunakan lepa.

Pada dinding tenggara dan dinding barat daya bastion barat daya terdapat lubang-lubang segi empat yang bagian atasnya terbuka (Foto-3). Di lantai bastion tepat pada bagian bawah lubang- lubang tersebut terdapat struktur balok batu karang berukuran antara $1 \mathrm{~m} \times 1 \mathrm{~m}$ sampai $1,30 \mathrm{~m} \times 1,30 \mathrm{~m}$. Lubang yang terdapat di bastion barat laut tersebut seluruhnya berjumlah 6 buah, yaitu 4 pada dinding barat daya dan 2 pada dinding tenggara bastion.

Bagian dalam benteng ini kosong dan dari pengamatan terhadap permukaannya tidak dijumpai sisa-sisa bangunan. Di luar benteng, yaitu di luar dinding keliling sisi timur, terdapat 17 umpak berbahan bata berlepa. Umpak-umpak tersebut berbentuk trapesium dengan ukuran sisi bawah $70 \mathrm{~cm} \times 70 \mathrm{~cm}$, sedangkan sisi atas berukuran $40 \mathrm{~cm} \times 40$ $\mathrm{cm}$. Di sisi selatan pintu masuk terdapat 10 umpak, sedangkan di sisi utara terdapat 7 umpak. Di sebelah timur 7 umpak tersebut di atas terdapat struktur balok batu karang berdenah persegi panjang dengan ukuran 3,4 m × 2,8 m (Gambar 2).

\section{III}

Pada dasarnya benteng adalah mesin perang yang dirancang untuk melayani kepentingan dan menjalankan sistem peperangan yang dianut oleh pemakainya. Dari sebuah studi tentang rancang bangun benteng sebagai sarana pertahanan, diketahui bahwa rancang bangun suatu benteng dipengaruhi oleh fungsi benteng itu sendiri pada masa 
penggunaannya (Anonim, 1991-1992).

Dengan demikian dari studi terhadap rancang bangun dan modifikasi yang berlangsung selama masa penggunaan suatu benteng akan dapat diketahui beberapa aspek yang berpengaruh terhadap rancang bangun tersebut, misalnya faktor pola ancaman pada masa penggunaan benteng itu sendiri. Pola ancaman adalah ancaman yang datang kepada pihak pengguna benteng maupun sebaliknya, yaitu ancaman dari pengguna benteng kepada pihak lain di luar benteng. Selain faktor fungsi, rancang bangun benteng biasanya berkaitan juga dengan faktor lain, seperti struktur-konstruksi dan geografis.

Telah diuraikan di atas bahwa denah benteng tersebut berbentuk segitiga dengan bastion pada masing-masing ketiga sudutnya. Sejauh ini bentuk denah segitiga merupakan desain benteng kolonial yang langka dijumpai di Indonesia, bahkan mungkin hanya satu-satunya di Indonesia. Kasus benteng berdenah segitiga lainnya adalah benteng di Panarukan, Jawa Timur. Selain bentuk denah segi empat yang biasa dijumpai pada benteng-benteng Kolonial, bentuk lain misalnya adalah segi lima dan segi delapan.

Dari segi fungsional, bentuk denah segi tiga sebenarnya kurang mendukung efektivitas penggunaan benteng itu sendiri. Secara teoritis, benteng berdenah segi banyak sampai dengan bulat sebenarnya lebih efektif untuk menjangkau (covering) daerah yang lebih luas di luar benteng. Hanya saja konstruksi denah segi banyak sampai dengan bulat kurang kuat / mantap dibanding dengan yang segi empat misalnya, sehingga denah segi empat memang paling sering digunakan. Kelemahan kemampuan benteng berdenah segi empat dalam menjangkau (coverage) kawasan disekitarnya diantisipasi dengan pembangunan bastion di empat sudutnya.

Sebaliknya semakin sedikit jumlah sudut dari denah benteng, maka semakin buruk kemampuan pengguna benteng untuk menjangkau daerah di luar benteng, walaupun hal itu telah diantisipasi melalui pembangunan bastion. Selain itu denah dari benteng yang bersegi sedikit, misalnya segitiga, cenderung kurang mendukung fungsi benteng secara maksimal, karena ruang di dalam benteng tidak efisien bagi kepentingan bermukim maupun pergerakan manusia sewaktu perang.

Memperhatikan bahwa pembangunan Benteng Kompeni di Jepara dilatarbelakangi oleh munculnya perang Trunajaya, maka "penyimpangan" bentuk denahnya tentu dilatarbelakangi oleh faktor yang sangat signifikan. Hal itu nampaknya berkaitan dengan faktor 
topografi dari keletakan benteng yang bersangkutan.

Sebagaimana telah disampaikan di atas bahwa Benteng Kompeni di Jepara tersebut berada di sebuah puncak bukit. Secara topografis bagian yang relatif datar dari puncak bukit tersebut berbentuk segitiga dengan luas sekitar 3700 meter persegi. Ketiga sudut dari bagian datar puncak bukit tersebut terletak di arah barat, timur laut, dan tenggara. Dalam pembangunannya, benteng Kompeni tersebut ditempatkan sesuai pada permukaan bidang datar itu, sehingga sudutsudut benteng berada pada sudut-sudut bidang datar tersebut.

Sedemikian rupa letak benteng pada puncak Bukit Danareja, sehingga dinding-dinding benteng sisi utara dan selatan langsung berbatasan dengan tebing-tebing yang relatif curam dengan kedalaman antara 3 meter sampai dengan 10 meter. Bahkan salah satu sudut bastion timur laut telah runtuh tererosi ke dalam tebing. Hanya pada bagian depan benteng (sisi timur), tebingnya relatif lebih landai. Di lain pihak, keberadaan tebing-tebing curam di sebelah luar benteng memberikan pengamanan tambahan yang bersifat alami, sehingga tidak diperlukan lagi adanya parit-parit (Jawa: jagang) di luar dinding benteng.

Hal yang juga dapat dinilai unik lain dari rancang bangun Benteng Kompeni di Jepara adalah tidak didapatinya sama sekali selasar di sepanjang dindingnya. Selasar pada umumnya dijumpai pada bentengbenteng kolonial di Jawa, misalnya Benteng Vredeburg (Yogyakarta), Benteng Vastenburg (Surakarta), Benteng Pendem (Cilacap), dan Benteng Willem II (Ungaran), walaupun tidak selalu menyeluruh di semua sisi benteng. Tidak ditempatkannya selasar pada desain benteng tersebut disebabkan karena elevasi permukaan lahan di dalam benteng tidak berbeda jauh dengan elevasi permukaan dinding benteng. Bahkan elevasi permukaan lahan di dalam bastion lebih tinggi lagi, sehingga pengguna benteng dapat dengan mudah melakukan kegiatan di seluruh tepi dinding bastion tanpa bantuan alat pemanjat sama sekali.

Selain menggunakan kondisi permukaan lahan bastion yang relatif tinggi, pengguna benteng juga memanfaatkan secara maksimal bangunan silinder yang terletak di sudut masing-masing bastion, baik sebagai pengintaian maupun penembakan.

Di dalam fungsinya sebagai mesin perang, bastion barat daya nampaknya memiliki nilai lebih dibanding dengan dua bastion yang lain. Di sisi selatan bastion barat daya terdapat 6 buah lubang penembakan yang mengarah ke tenggara serta barat daya. Masing-masing lubang penembakan tersebut dilengkapi dengan semacam pelataran di 
bawahnya, sebagai fasilitas bagi pengguna benteng untuk menempatkan peralatan perang (meriam?) (Gambar 2). Sebaliknya di kedua bastion lain maupun di bagian lain dari dinding benteng tidak terdapat lubang-lubang penembakan semacam itu.

Penempatan lubang-lubang tersebut menyiratkan bahwa ancaman terbesar datang dari arah selatan benteng. Kemungkinan pasukan Trunajaya berbasis di kota Jepara dan menghimpun serangan dari sisi selatan Sungai Wiso. Sisi selatan bastion barat daya Benteng Kompeni tersebut mampu menjangkau jalan raya yang berada di sebelah selatan Sungai Wiso (sekarang Jalan Veteran) (Gambar 1). Pada ruas jalan tersebut, khususnya yang berada di sebelah selatan benteng, bermuara beberapa jalan yang datang dari Semarang (sekarang Jalan Sunan Mantingan dan Jalan Ratu Kalinyamat).

Dewasa ini kawasan yang dimaksud merupakan pemukiman dan pasar yang relatif padat. Kemungkinan dahulu fungsi kawasan tersebut tidak jauh berbeda dengan sekarang, sehingga memiliki prospek yang bagus guna mendukung segi-segi logistik pasukan yang berperang. Dengan demikian maka daerah ini merupakan sasaran pokok pengawasan dan penyerangan oleh pihak Kompeni yang bertahan di benteng.

Selain itu bastion barat daya juga menjangkau pandangan ke lokasi pelabuhan lama (boom). Pelabuhan tersebut berada di sisi selatan Sungai Wiso, di tepi barat kota Jepara. Pandangan dari bastion barat daya bahkan dapat menjangkau alur Sungai Wiso dari pelabuhan hingga muara. Sebagaimana diketahui, Sungai Wiso dan pelabuhan lama Jepara memiliki peran penting dalam sejarah sosial-ekonomi Jawa, sejak era Demak sampai dengan Mataram (Hendro, 1989). Kesemuanya itu memberikan indikasi bahwa bastion barat daya dengan fasilitas penem-bakan meriamnya berfungsi penting untuk "mengontrol" pelabuhan itu sendiri, maupun alur keluar-masuk kapal menuju pelabuhan.

Memang masih menjadi pertanyaan, mengapa sisi timur benteng tidak dilengkapi dengan fasilitas perang sebagaimana yang dijumpai pada bastion barat daya?. Padahal diketahui bahwa sisi timur ini rawan ter-hadap ancaman serangan, karena kemiringan lahannya relatif landai se-hingga memudahkan untuk dicapai dari Kota Jepara. Kemungkinan di si-si ini ditempatkan pula fasilitas perang yang memadai, hanya saja data-nya belum lengkap diperoleh. Walaupun demikian di bagian depan ben-teng terdapat beberapa elemen bangunan yang tidak terdapat pada bagi-an-bagian lain dari benteng, yaitu umpak-umpak dan sebuah pelataran rendah. Belum dapat dipastikan sejauh manakah peran dari 
elemen-elemen bangunan tersebut dalam memperkuat pertahanan sisi timur Benteng Kompeni ini. Apakah terdapat kemungkinan untuk menempatkan meriam pada pelataran rendah tersebut?. Di samping itu apakah umpak-umpak yang terdapat di sisi utara maupun selatan pintu masuk tersebut merupakan bekas-bekas bangunan, yang kemungkinan digunakan pula sebagai semacam gardu penjagaan?. Telah pula disebutkan di atas bahwa di dalam benteng tidak didapati sisa-sisa sarana pemukiman (bangunan) sebagaimana yang biasa dijumpai pada benteng-benteng yang lain. Hal ini disebabkan karena pada dasarnya keberadaan bangunan (permanen) di area dalam benteng akan mengganggu pergerakan pa-ra pengguna benteng di dalam situasi perang. Faktor denah yang ber-bentuk segitiga dan faktor tidak adanya selasar di dinding benteng meng-akibatkan area di tengah benteng berfungsi penuh untuk mendukung pergerakan satuan-satuan militer di dalam melakukan tugasnya. Area terse-but harus tetap terbuka sehingga pergerakan satuan-satuan pasukan bisa berlangsung secara efektif dan leluasa.

Mengingat tidak dimungkinkan adanya fasilitas pemukiman (permanen) di dalam benteng, maka fasilitas pemukiman yang sesuai dengan kepentingan itu adalah tenda. Sejauh mana penggunaan tenda di Benteng Kompeni Jepara mungkin dapat dilacak melalui dokumendokumen sejarah.

Pendirian sebuah benteng sebagai sarana pertahanan, tentu tidak dapat dilepaskan dari faktor taktik dan strategi militer pada masanya. Hal itu berkaitan dengan pola ancaman yang harus diantisipasi oleh keberadaan benteng itu sendiri. Di samping itu tentunya dipertimbangkan pula faktor lain yang dapat menunjang fungsi benteng sebagai mesin perang, misalnya faktor geografis. Dari rancang bangun sebuah benteng dilengkapi dengan tinjauan atas keletakan benteng itu, dapat diungkapkan beberapa hal yang menyangkut strategi pertahanan Belanda di masanya. Dengan demikian akan tampak beberapa hal yang melatari perancangan serta peletakan benteng itu sendiri.

Dari rancang bangun maupun keletakan Benteng Kompeni di Jepara dapat dikemukakan beberapa hal sebagai berikut.

1. Denah benteng Kompeni di Jepara dipengaruhi oleh faktor topografis dari Bukit Danareja yang ditempatinya. 
2. Benteng Kompeni tersebut didirikan dengan me-manfaatkan bentang lahan yang tersedia, yaitu sebuah bukit di tepi Laut Jawa. Dengan demikian pandangan akan terbuka ke arah daratan dan alur Sungai Wiso di sekitarnya. Selain pandangan yang lebih terbuka dan mampu mengontrol titik-titik yang penting di sekitarnya, keletakannya juga memberikan kemampuan untuk melakukan ancaman melalui persenjataan yang ditempatkan pada benteng tersebut.

3. Di lain pihak unsur bukit itu sendiri sangat menunjang strategi pertahanan yang dibangun di tempat itu, mengingat topografinya merupakan sistem pertahanan alami.

\section{KEPUSTAKAAN}

Anonim, 1991-1992. Studi Kawasan Cagar Budaya Yogyakarta. Yogyakarta : P.T. Kerta Gana.

de Graaf, H.J. 1949. Geschiedenis van Indonesie. 's- Gravenhage I Bandung : N.V. Uitgeverij W. van Hoeve.

1987. Runtuhnya Istana Mataram. Jakarta $P T$. Pustaka Utama Grafiti.

1989. Terbunuhnya Kapten Tack. Jakarta P.T. Pustaka Utama Grafiti.

Hendro, Eko Punto. 1989 Pola Perkotaan dan Pemukiman Kuno di Jepara, dalam Proceedings Pertemuan IImiah Arkeologi V. Ikatan Ahli Arkeologi Indonesia.

Olthoff, W.L. 1941. Poenika Serat Babad Tanah Djawi Wiwit Saking Nabi Adam Doemoegi ing Taoen 1647. 's-Gravenhage M.Nijhoff. 


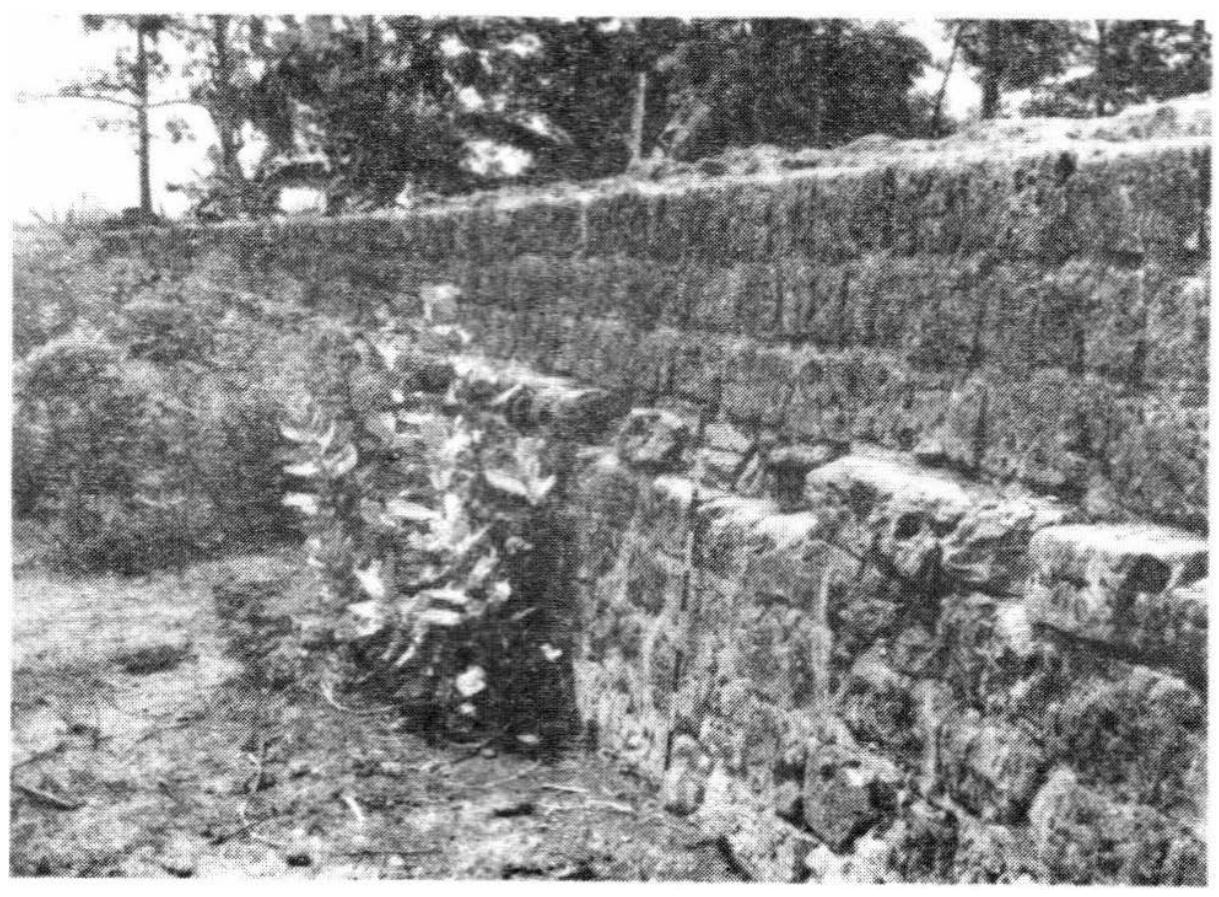

Foto 1 Tembok benteng yang disusun dari balok-balok batu karang.

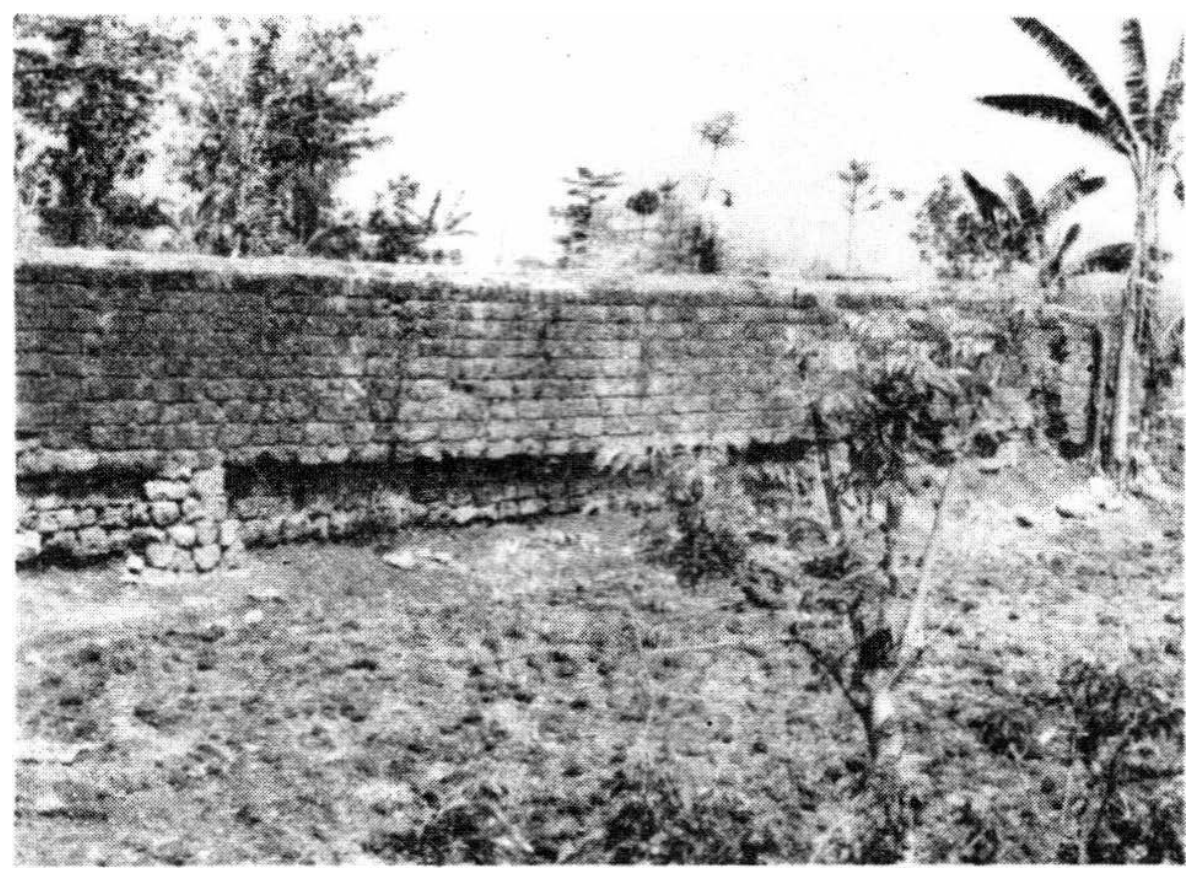

Foto 2: Tinggi tembok keliling yang tersisa saat ini (dilihat dari bagian dalam benteng). 


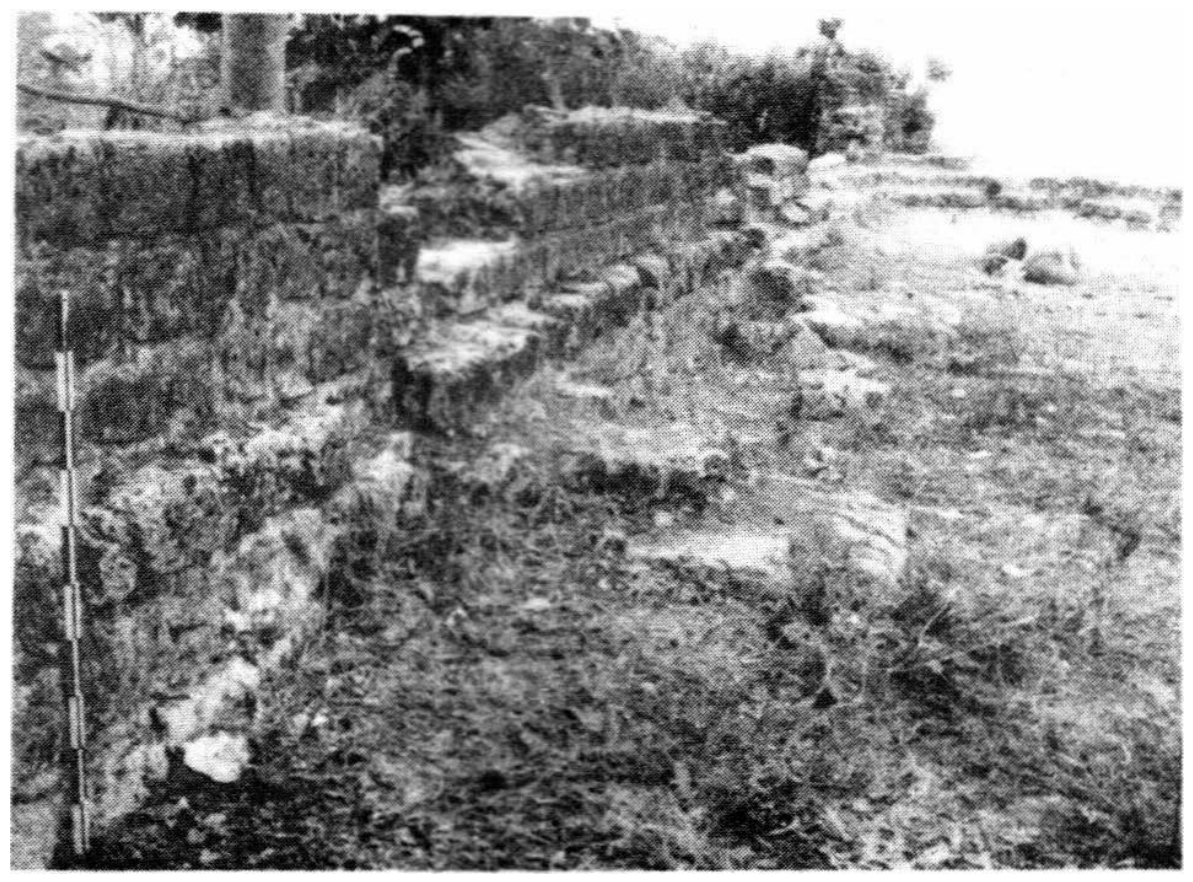

Foto 3 : Bekas tempat meletakkan meriam di bastion barat daya. 


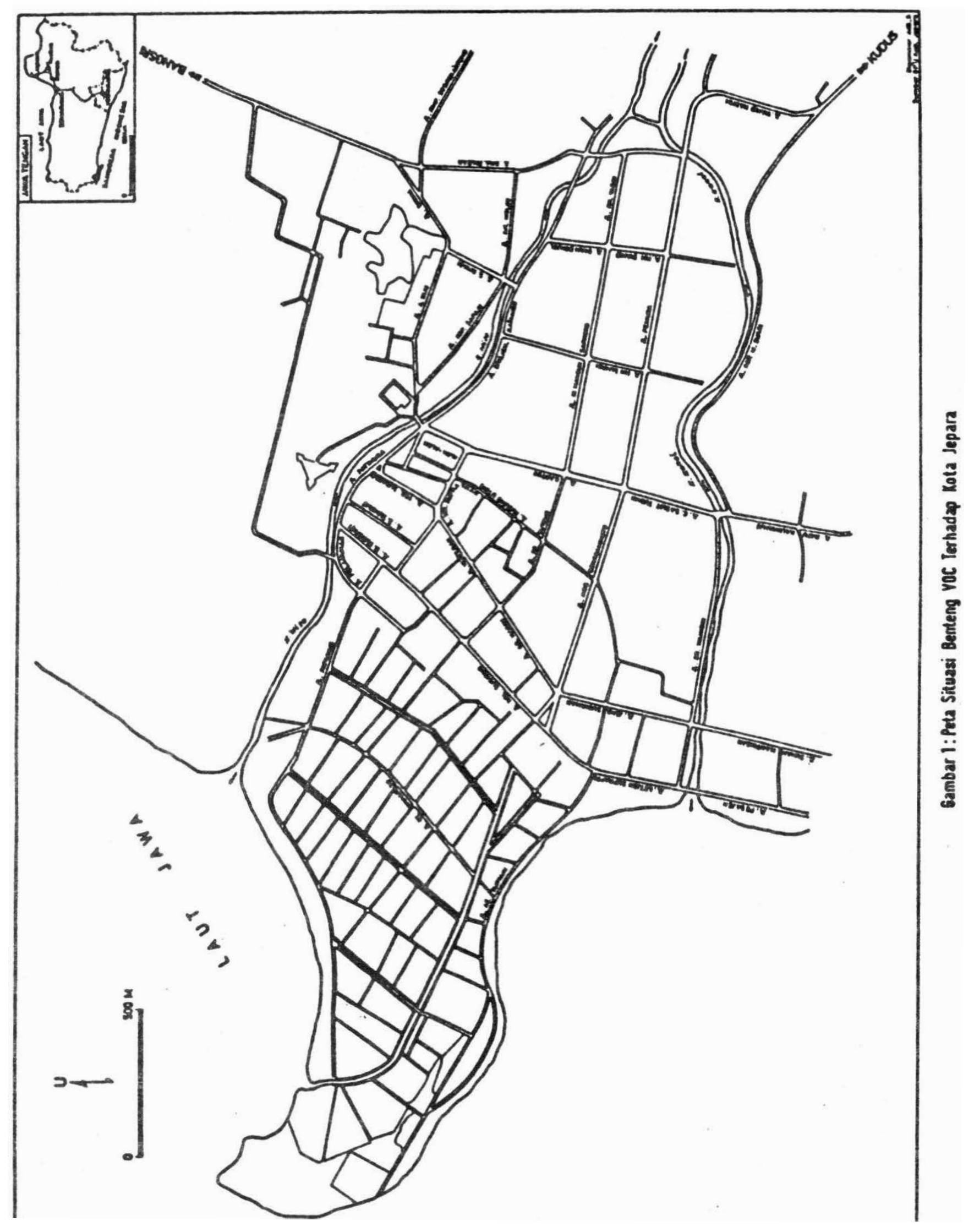




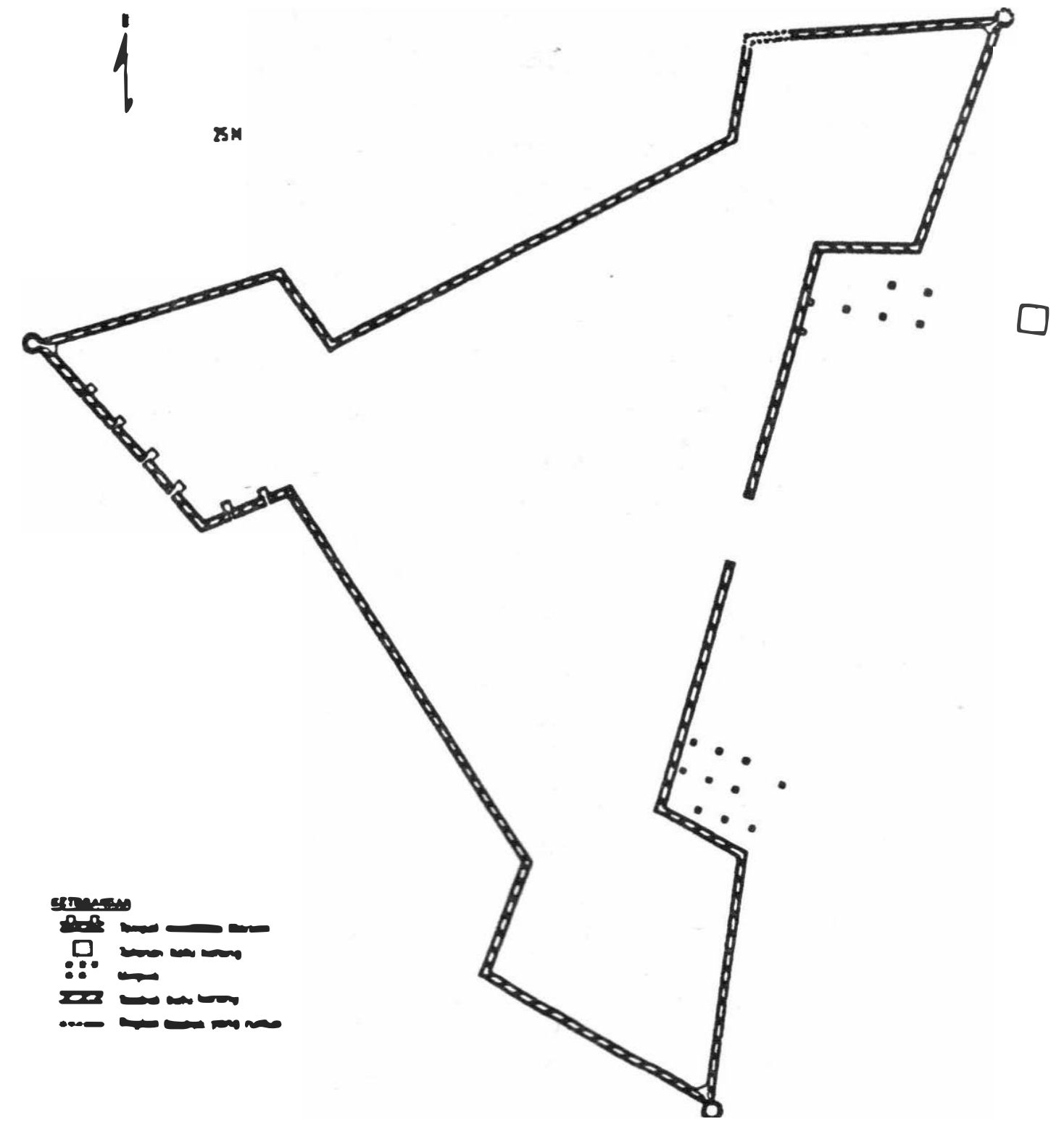

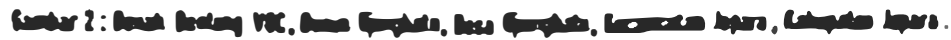

